Check for updates

Plymouth

Cite this as: BMJ 2021;373:n1539 http://dx.doi.org/10.1136/bmi.n1539 Published: 15 June 2021

\section{Covid-19: Deaths in Brazil near half a million as controversial football tournament gets under way}

Luke Taylor

Brazil continues to report a high number of covid-19 infections and deaths against the backdrop of a parliamentary inquiry into the government's management of the pandemic and a controversial football tournament plagued by virus outbreaks.

The country is expected to reach half a million deaths from covid-19 in the coming days as teams from around Latin America compete in the Copa America, which kicked off in Brasilia on 13 June.

"The situation is not coming under control since [politicians] are still in denial of the pandemic, including the president," said Helena Nader, biomedical scientist at the Federal University of São Paulo and former president of the Brazilian Society for the Advancement of Science.

At least 31 Copa America players and 10 members of staff have been infected so far, as health experts and players alike voice their concern over the health risk posed by the controversial decision to host the tournament in one of the nations worst hit by covid-19 in the world.

The tournament was relocated to Brazil after civil unrest prevented Colombia from hosting it and as surging coronavirus infections prevented Argentina from being its replacement. Brazil's suitability to host the competition has sparked protests as it too has failed to get the pandemic under control.

\section{Sinovac vaccine}

Miguel Nicolelis, a Brazilian neuroscientist who is a professor at Duke University in North Carolina, tweeted: "24h of the Coronavirus Cup of America and 41 are already infected. Forty-one people who did not need to have had contact with a lethal virus were exposed to the lethal risks of covid-19. All for the greed of a few leaders. How many more will be exposed in the coming weeks?"

Brazil has recorded 17.5 million cases of covid-19 and 488 ooo related deaths, the second deadliest total in the world. Public health experts blame President Bolsonaro-who is being investigated for his role in the crisis-for refusing to enact a national lockdown, disseminating misinformation, and playing down the threat of the novel coronavirus.

Although covid-19 fatalities are down on their mid-April peak when the country was recording more than 4000 deaths a day, mortalities remain high and have climbed in the past week. Brazil reported 2037 deaths on 12 June and a seven day average of 1963 , up from 1689 deaths and a 1639 seven day average a week earlier.
Hospital occupancy rates are growing in regions such as São Paulo, where $82 \%$ of intensive care beds are occupied, rising by $17 \%$ in the past month.

The country's ongoing vaccine rollout offers a way out of its health crisis. In the city of Serrana in the state of São Paulo, deaths decreased by $95 \%$ and symptomatic cases by $80 \%$ after most of the population was given China's Sinovac vaccine in a large scale trial. Only $11 \%$ of Brazilians nationwide have received two doses of a vaccine, however, and $15 \%$ a single dose.

\section{Competing states}

Gerson Salvador, an infectious disease specialist and doctor working at the University of São Paulo, said, "Immunisation is advancing slowly, given the country's potential, as it is one of the few in Latin America to have a large public health system and vaccine factories.”

Salvador blamed the slow rollout on Bolsonaro's failure to secure vaccines early on. The president ignored vaccine offers from Pfizer last year, its chief executive for Latin America told the commission investigating the government's management of the pandemic.. Rather than a centralised approach utilising Brazil's unified health system (SUS), individual states are now competing to acquire their own vaccine supplies. "The political reality of Brazil defies any dystopian fiction,” said Salvador.

Brazil struck a deal with AstraZeneca in June 2020 to manufacture up to 100 million doses of a vaccine candidate, but the materials needed to produce them are scarce, said Nader. Material shortages have also delayed Brazil's production of the Chinese Sinovac vaccine, and Nader does not expect vaccines produced in Brazil to speed up the rollout until October at the earliest.

Doctors are calling for a reversal of the government's stance in favour of science, but this seems "impossible" as the government continues to push for the reopening of businesses and events at the cost of public health, said Nader, who added, "We are in the midst of a tremendous crisis."

We amended this story on 16 June 2021 to clarify the total referred to in this sentence: "Brazil has recorded 17.5 million cases of covid-19 and 488000 related deaths, the second deadliest total in the world." We initially described it as "the third highest total in the world," which related to the infection rate rather than the number of deaths.

This article is made freely available for use in accordance with BMJ's website terms and conditions for the duration of the covid-19 pandemic or until otherwise determined by BMJ. You may use, download and print the article for any lawful, non-commercial purpose (including text and data mining) provided that all copyright notices and trade marks are retained. 